korzystania pomocy z funduszy strukturalnych. Zaznacza się, że reformy w obrębie struktur i mechanizmów w tym obszarze są nieustanne, a Komisja swoje uwagi zgłasza do wszystkich państw członkowskich (s. 498).

Książka zawiera udaną próbę komplementarnej analizy Unii Europejskiej jako współczesnego aktora stosunków międzynarodowych. Opracowania prezentują rzeczywistość instytucjonalną i polityczno-prawną. Wiele do zrobienia pozostaje w zakresie opracowań badawczych w kwestiach: życia kulturalnego, postaw, zachowań, aspiracji obywatelskich, wartości i kultury politycznej. Prezentowana książka w istotnej mierze poszerza wiedzę o roli Unii Europejskiej na arenie międzynarodowej. Wskazuje się na Unię jako znaczący podmiot w generowaniu ładu międzynarodowego. Dostrzega się Unię Europejską w procesie globalizacyjnym, w którym główną siłę napędową stanowi postęp naukowo-techniczny oraz promowane zasady liberalnej gospodarki rynkowej. Zaprezentowane w książce studia dowodzą, że UE w coraz większym stopniu wywiera wpływ na relacje ponadnarodowe, stając się jednocześnie kreatorem, koordynatorem oraz sprawcą stosunków międzynarodowych. Jej istota, potencjał oraz zaangażowanie w sprawy polityczne, gospodarcze i społeczne powoduje, że instytucja ta jest wiodącym aktorem środowiska międzynarodowego. Jest to praca rzetelna, oryginalna i dobrze udokumentowana materiałami źródłowymi. Zawarte w niej sądy nie są formułowane arbitralnie, a redaktor jest otwarty na argumenty badaczy. Książka może być wykorzystana w szkołach i na uczelniach, a także stanowi oryginalną lekturę dla wszystkich zainteresowanych tematyką europeistyki i stosunków międzynarodowych.

MAREK MOLIŃSKI

\title{
Pakiet klimatyczno-energetyczny. Analityczna ocena propozycji Komisji Europejskiej, Urząd Komitetu Integracji Europejskiej, Departament Polityki Integracyjnej, Warszawa 2008, ss. 553.
}

Problematyka zarówno bezpieczeństwa energetycznego, w tym możliwości wykorzystania odnawialnych źródeł energii, jak i redukcji emisji gazów cieplarnianych, stanowi jeden z kluczowych elementów politycznej agendy w ramach Unii Europejskiej. Jej znaczenie potwierdza m.in. przyjęcie przez Komisję Europejską w styczniu 2008 roku pakietu klimatyczno-energetycznego, w którym znalazły się propozycje ustanowienia instrumentów shużących realizacji celów przyjętych przez Radę Europejską w marcu 2007 roku. Ich osiągnięcie miało, w zamierzeniu, stać się motorem postępu w negocjacjach dotyczących globalnego porozumienia w sprawie ograniczenia emisji po roku 2012.

Omawiana publikacja stanowi ocenę propozycji Komisji Europejskiej. Bez niej, a przede wszystkim bez wnikliwego rozpatrzenia postulatów zgłaszanych w trakcie rozmów, jak to zostało podkreślone w Stowie wstępnym, nie byłby możliwy aktywny, zwieńczony sukcesem udział polskiego rządu w tych negocjacjach. Urząd Komitetu Integracji Europejskiej zdecydował o konieczności zaangażowania ekspertów zewnętrznych, których zadaniem było wspieranie administracji przez przygotowywanie opracowań analitycznych dotyczących poszczególnych elementów pakietu klimatyczno-energetycznego.

Pierwszym zagadnieniem przedstawionym w publikacji jest wybór właściwej podstawy prawnej aktów wspólnotowego prawa wtórnego, przy czym C. Mik w sposób szczególny uwzględnia projekty aktów należących do pakietu klimatyczno-energetycznego. Celem analizy jest w tym przypadku m.in. dokonanie oceny zaproponowanej przez Komisję Europejską podstawy prawnej w projektach legislacyjnych wchodzących w skład pakietu klimatyczno-energe- 
tycznego. Autor podkreśla, iż projekty regulacji często łączą różne aspekty przedmiotowe, objęte odrębnymi normami kompetencyjnymi. Rodzi to konflikty między instytucjami, między państwami członkowskimi a instytucjami, jak również między jednostkami a instytucjami. Kończą się one niejednokrotnie w Sądzie Pierwszej Instancji lub Europejskim Trybunale Sprawiedliwości. Ani traktaty założycielskie, ani akty prawa wspólnotowego pochodnego nie określają zasad i kryteriów wyboru podstaw prawnych. Nie przesądzają, czy dany akt ma być oparty na jednej, dwu lub większej liczbie podstaw prawnych. Pewne reguły w tej kwestii przynosi jednak orzecznictwo, zwłaszcza Europejskiego Trybunału Sprawiedliwości, który uznał, iż wybór określonej podstawy prawnej nie może być wynikiem subiektywnego przekonania instytucji projektującej go lub uchwalającej co do zamierzonego celu tego aktu. Podstawa prawna nie może także być uzależniona od woli określonej instytucji włączenia się w większym zakresie, niż przewidują to traktaty, w uchwalanie aktu. Decydować mają czynniki obiektywne, jak cel i treść aktu. Z zagadnieniem tym wiąże się analiza projektów legislacyjnych składających się na pakiet klimatyczno-energetyczny.

Jako drugi z problemów, poruszono kwestię gospodarczych i technicznych skutków wprowadzenia w sektorze energetycznym systemu aukcyjnego dla emisji dwutlenku węgla. Działanie to wiąże się z bezpieczeństwem dostaw energii elektrycznej ze źródeł krajowych, ograniczeniami sieciowymi wynikającymi ze zwiększenia międzysystemowego przesyłu energii elektrycznej i sytuacją przedsiębiorstw energetycznych na rynku. W ocenie Krzysztofa Żmijewskiego, najważniejsze zagrożenia dla Polski dotyczą wykupienia całości uprawnień z aukcji przez słabo nawęglone i silne gospodarki; spekulacyjnego wykupu uprawnień przez międzynarodowe instytucje finansowe i fundusze inwestycyjne; wywindowania cen praw do emisji na poziom ponad 100 euro za tonę $\mathrm{CO}_{2}$, co w konsekwencji może wywołać kryzys ekonomiczny w co najmniej części państw europejskich.

Kolejną z omawianych kwestii jest obecność tzw. windfall profits w sektorze elektroenergetycznym w Polsce oraz ocena możliwości zastosowania mechanizmów zapobiegawczych. Sam termin windfall profits oznacza wzrost zysków oraz cen energii nieadekwatny do faktycznych kosztów wynikających z konieczności modernizacji infrastruktury w celu redukcji emisji dwutlenku węgla do atmosfery. Innymi słowy, jest to przeniesiony w cenę energii koszt alternatywny emisji $\mathrm{CO}_{2}$. Zjawisko to wiązane jest z bezpłatną alokacją uprawnień do emisji dwutlenku węgla (EU Allowances - EUAs) w unijnym Systemie Handlu Uprawnieniami do Emisji (EU ETS). Jak stwierdzają autorzy opracowania, analiza średnich wartości dla sektora elektrowni w latach 2004-2008 wskazuje na brak związku między ceną zbytu energii elektrycznej i poziomem zyskowności sprzedaży energii elektrycznej a ceną uprawnień emisyjnych, co stanowi podstawę do konstatacji, iż indukowane darmową alokacją uprawnień zjawisko windfall profits jeszcze w Polsce nie wystąpiło. Niemniej, zmiany zachowań na rynku producentów energii elektrycznej, w tym zmiany cen energii elektrycznej na Towarowej Giełdzie Energii, mogą wskazywać na jego początki. Wielość czynników występujących w tym samym czasie nie pozwala jednak na potwierdzenie tego w sposób jednoznaczny.

Szczegółowej analizie poddano także relokację źródeł energii elektrycznej dla polskiego systemu elektroenergetycznego oraz przenoszenie zakładów z sektorów produkujących cement, stal, szkło oraz aluminium poza granice RP i UE na skutek pojawiania się nowych przeszkód dla przedsiębiorców. Dokonano oceny proponowanych mechanizmów zapobiegania temu zjawisku. Autorzy zakładaja, iż wprowadzenie systemu aukcji będzie niosło z sobą zagrożenie transferu aktywności przedsiębiorstw obciążonych koniecznością zakupu uprawnień do emisji do państw, które takich obciążeń nie wprowadzają. W przypadku energetyki może również nastąpić przeniesienie produkcji do tych państw członkowskich UE, w których niski jest udział kopalnych surowców w energetyce. Relokacja poza UE spowodowałaby swoisty „przeciek” emisji dwutlenku węgla (ang. carbon leakage). Aukcje prowadziłyby do poprawienia pozycji konkurencyjnej na wspólnym rynku przedsiębiorstw energetycznych mających lepszą strukturę emi- 
syjną. Te dwa zjawiska składają się na problem relokacji źródeł energii, który w szczególny sposób dotyczy opartej na węglu polskiej energetyki. Jako najbardziej prawdopodobny scenariusz wskazuje się import energii elektrycznej z Litwy i Ukrainy, z elektrowni jądrowych Ignalina i Chmielnicka oraz elektrowni wodnych.

Końcowy element analizy stanowi ocena możliwości wykorzystania przez Polskę czternastoprocentowego wzrostu emisji gazów cieplarnianych do roku $2020 \mathrm{w}$ sektorach, które nie zostały objęte systemem EU ETS. Bolesław Jankowski, uwzględniając bazowy i umiarkowany scenariusz makroekonomiczny, przedstawia prognozę popytu na energię w sektorach non ETS oraz emisji dwutlenku węgla z procesów produkcyjnych i pozostałych źródeł (produkty mineralne, przemysł chemiczny, produkcja metali, inne).

W omawianej publikacji zaprezentowano szerokie spektrum zagadnień, szczególną uwagę poświęcając jednak przeanalizowaniu wpływu pakietu na strukturę zaopatrzenia Polski w energię oraz bezpieczeństwa energetycznego, redukcji emisji dwutlenku węgla, wpływu pakietu na konkurencyjność branż energochłonnych oraz samego sektora elektroenergetycznego. Szczegółowej analizie poddano także metody alokacji uprawnień do emisji.

MARTA ZOBENIAK Poznań

\section{Misje cywilne Unii Europejskiej, red. Beata Przybylska-Maszner, Wydawnictwo Naukowe WNPiD UAM, Poznań 2010, ss. 312.}

Publikacja pt. Misje cywilne Unii Europejskiej, została wydana pod redakcją Beaty Przybylskiej-Maszner, przez Wydawnictwo Naukowe Wydziału Nauk Politycznych i Dziennikarstwa UAM. Dotyka szerokiego i istotnego współcześnie obszaru działań zewnętrznych UE, w ramach tzw. Wspólnej Polityki Zagranicznej i Bezpieczeństwa. We wprowadzeniu do książki, stwierdzone zostało nawet, że owo ,zaangażowanie operacyjne jest najważniejszym przejawem skuteczności Unii na arenie międzynarodowej" ${ }^{\prime \prime}$. Sama praca została podzielona na siedem zróżnicowanych tematycznie rozdziałów, skupiających w sobie artykuły aż szesnastu autorów. Indywidualne podejście każdego z autorów do problematyki z zakresu misji cywilnych UE, idealnie oddaje skomplikowaną charakterystykę wyzwań, przed jakimi został postawiony personel poszczególnych operacji. Książka obok stworzenia niejako mapy aktywności w zakresie misji cywilnych poza granicami UE, jest niewątpliwie niezmiernie ważnym głosem w dyskusji nad ich skutecznością oraz przyszłością tego rodzaju działań.

Pierwszy rozdział porusza problematykę procesu kształtowania się zdolności operacyjnych UE w zakresie wspólnej polityki bezpieczeństwa i obrony. Jego autor - Zbigniew Czachór, przybliżył czytelnikowi historię tworzenia kluczowych podstaw prawnych dla funkcjonowania misji poza granicami UE, o których jest mowa w dalszych rozdziałach publikacji. Jednocześnie wskazał na najważniejsze wyzwania stojące przed UE, w obliczu tzw. Europejskiej Strategii Bezpieczeństwa, do których zaliczone zostały m.in. proliferacja broni masowego rażenia, rozwój terroryzmu i przestępczości zorganizowanej, ale także kwestie współczesnego cyberterroryzmu coraz częściej zagrażającego rozwiniętym państwom świata czy też bezpieczeństwa energetycznego. Niezmiernie ciekawym elementem rozdziału jest zarysowanie przez autora zdolności operacyjnych UE, w kontekście Traktatu z Lizbony. Przeprowadzona analiza przedstawia w sposób bardzo czytelny drogę ku rozszerzeniu zakresu możliwości oddziaływania UE w sytuacjach kryzysowych, od trak-

1 B. Przybylska-Maszner, Wprowadzenie, w: Misje cywilne Unii Europejskiej, red. B. Przybylska-Maszner, Poznań 2010, s. 7. 